\title{
Decomposition of ethnic heterogeneity on growth
}

Eiji Yamamura and Inyong Shin

ISSN: 2031-4892

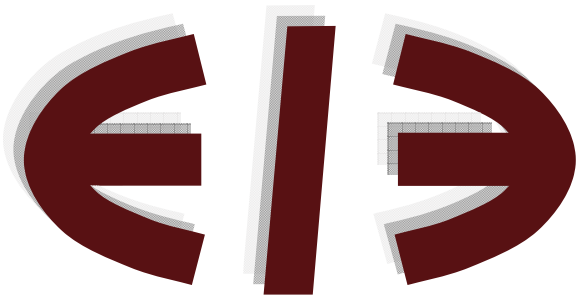

EERI

Economics and Econometrics Research Institute Avenue de Beaulieu 1160 Brussels

Belgium

Tel: +3222988491

Fax: +3222988490

www.eeri.eu 


\title{
Decomposition of ethnic heterogeneity on growth
}

\author{
Eiji Yamamura (Seinan Gakuin University) \\ Inyong Shin (Asia University)
}

\begin{abstract}
Ethnic heterogeneity influences economic growth through various channels such as efficiency improvement and capital accumulation. However, it is open to discussion exactly how ethnic heterogeneity affects these channels. Hence, this paper attempts to examine the effects of heterogeneity on economic growth using data envelopment analysis. The empirical results of the estimations show that heterogeneity has a negative effect on efficiency improvements. However, heterogeneity has no effect on capital accumulation. This implies that ethnic heterogeneity hinders positive externalities such as information spillover, which hampers economic growth.
\end{abstract}

Running title: Ethnic heterogeneity on growth

Keywords: Ethnic fractionalization, Ethnic polarization, Efficiency improvement, Capital accumulation.

JEL classification: $\mathrm{H} 11, \mathrm{O} 43$ 


\section{INTRODUCTION}

Since the 1990s, there has been a growing interest among economic researchers in the relationship between ethnic diversity and economic performance (Alesina and La Ferrara, 2005). Easterly and Levine (1997) showed a negative association between ethnic heterogeneity and economic growth. Ethnic heterogeneity may influence economic growth through a variety of channels. First, ethnic heterogeneity is found to reduce investment (Mauro, 1995; Montalvo and Reynal-Querol, 2005a, 2005b). ${ }^{1}$ Hence, the heterogeneity reduced capital accumulation, impeding economic growth ${ }^{2}$. Second, ethnic heterogeneity is positively associated with the probability of conflict (Montalvo and Reynal-Querol, 2005a, 2005b), while heterogeneity is negatively related to trust (Dincer, 2011) ${ }^{3}$. Trust plays a key role in reducing transaction costs in the market (Zak and Knack, 2001). Thus, we predict that ethnic heterogeneity impedes not only market transactions but also information spillover (learning from others). This inevitably hinders economic growth. However, the effect of ethnic heterogeneity on growth is open for discussion ${ }^{4}$. Thus, it is worthwhile to investigate through which channels ethnic heterogeneity affects growth.

Data envelopment analysis (hereafter, DEA) enables us to analyze channels of economic growth. DEA constructs a world production frontier and then decomposes labor productivity growth to three components: technological catch-up, capital deepening, and technological change (Kumar and Russell, 2002) ${ }^{5}$. In addition, researchers can use regression analysis to examine how initial outputs per worker influence these components (Yamamura and Shin, 2007a, 2007b, 2008; Yamamura, 2011). Hence, this paper uses DEA.

This paper aims to examine influence of heterogeneity on growth and so provide new empirical evidence by analyzing the channels through which the heterogeneity affects growth. The key finding is that heterogeneity has a negative effect on efficiency

\footnotetext{
1 Previous works examined the effect of religious heterogeneity on economic development, which relate to works exploring the influence of ethnic heterogeneity (Alesina et al., 2003; Montalvo and Reynal-Querol, 2003).

2 Alesina et al. (1999) used United States data to show that shares of spending on productive public goods are inversely related to a city's (metro area's/county's) ethnic fragmentation.

${ }^{3}$ Heterogeneity is found to influence government size (Lind, 2007). This also possibly affects economic performance and growth.

${ }_{4}$ Heterogeneity, however, appears to have a contrasting effect: social diversity (which seems to be captured partly by ethnic heterogeneity) is thought to cause innovation (Jacobs, 1969, 1984). If this is true, then heterogeneity is thought to enhance economic growth. In DEA, technological progress, regarded as a proxy for innovation, is exogenously determined. In other words, technological progress is assumed to be determined for the countries. Hence, this paper cannot examine the influence of ethnic heterogeneity on innovation.

5 The seminal work of Nishimizu and Page (1982) attempted to decompose total productivity growth into technological progress and technical efficiency change.
} 
improvements, which results in the impediment of growth. The rest of this paper is organized as follows: two testable hypotheses are proposed in Section 2; Section 3 describes the data and estimation strategy; Section 4 exhibits the estimation results; and Section 5 concludes.

\section{HYPOTHESIS}

The engine of economic growth seems to stem from information spillover (Marshall, 1920). Positive externalities, via information spillover among various firms and groups, are expected to arise if face-to-face interaction among workers occurs. ${ }^{6}$ Information spillover is considered to enhance efficiency improvement, resulting in economic growth. However, various types of workers including experts are less likely to interact if workers are polarized. Easterly (2001) argued, "Suppose that people in linguistic groups associated primarily with people from their group and not with people from other groups. Then the knowledge creation coming from highly educated is valuable to you only if those people consist of your own group. Knowledge leaks within ethnic groups and not across ethnic groups" (Easterly, 2001, 271-272). This is consistent with the argument that information flows are weaker in a heterogeneous population, which prevents individuals from learning about their neighbors' experiences (Munshi, 2004). If this holds true, heterogeneity has a detrimental influence on information spillover. Furthermore, there appears to be a further mechanism. It is argued that trust contributes to economic growth (e.g., Beugelsdijk, et al., 2004; Beugelsdijk and van Schaik, 2005; Zak and Knack, 2001). This is in part because trust reduces the transaction cost among agents. However, Dincer (2011) provided evidence that ethnic heterogeneity is negatively associated with the level of trust. If this is true, then heterogeneity reduces trust and therefore increases transaction costs. Inevitably, the market does not function well, which in turn reduces positive externalities such as information spillover. Accordingly, economic growth is hindered. This argument leads us to postulate Hypothesis $1^{7}$ :

Hypothesis 1: Racial heterogeneity impedes efficiency improvements, which hampers economic growth.

\footnotetext{
6 Thornton and Thompson (2001), using micro-level data on wartime shipbuilding, suggest that learning spillovers were a significant source of productivity growth.

7 Mauro (1995) exhibits a negative and significant correlation between ethnic heterogeneity and institutional efficiency. Institutional efficiency is positively associated with economic efficiency. It follows then, with the exception of the information spillover channel, that ethnic heterogeneity impedes efficiency improvements.
} 
Ethnic heterogeneity is considered to increase the number of interest groups because the interests of each group are diverse and conflicting. A rent-seeking model shows that resources spent by each group to obtain political power can be considered a social cost (Mueller, 2003). In this model resources are allocated to nonproductive behavior and not into productive investments. To put it in another way, heterogeneity causes rent-seeking behavior and so reduces investment. It is also possible that that ethnic heterogeneity increases the likelihood of political conflict, creating an instable and uncertain country. As a consequence, investment is reduced in a heterogeneous society (Montalvo and Reynal-Querol, 2005a, 2005b) ${ }^{8}$. Considering the arguments above, we propose hypothesis 2 .

Hypothesis 2: Racial heterogeneity impedes capital accumulation, which hampers economic growth.

\section{DATA AND ESTIMATION STRATEGY}

Kumar and Russell (2002) used DEA to construct a cross-country data set by decomposing labor productivity growth into three components. They conducted a simple OLS regression model. In that model, the dependent variables were the percentage changes between 1965 and 1990 for output per worker, technological change, the efficiency index, and the capital accumulation index. Output per worker in 1965 was an independent variable. In their estimations, both unobservable individual and time effects were ignored. However, as suggested by Yamamura and Shin (2007 a), this can led to estimation bias.

Following Kumar and Russell (2002), this paper also uses DEA to construct a panel dataset for 57 countries, from 1965 to 1990, using the Penn World Table. In Figures 1(1) and (2), the vertical and horizontal axes indicate output per worker and capital stock per worker, respectively. Figure 1(1) illustrates the frontier line and location of each country in 1960, whereas Figure 1(2) illustrates the frontier line and location of each country in 1990. In the Appendix, Table A1 shows the codes for the countries used in each figure, matched with the name of country. Compared with 1960 illustrated in Figure

\footnotetext{
8 A secured property right is considered to provide an incentive to invest and therefore creates capital accumulation. Isaksson (2011) used cross-countries data to present evidence that social division measured in terms of ethnic fractionalization weakens the association between property rights institutions and income. If this is true, then heterogeneity reduces the incentive to invest even when property rights are well secured.

9 Kumar and Russell (2002) admitted that their method includes the possibility of an implosion of the technological frontier. Henderson and Russell (2005) precluded an implosion of the frontier over time. In this paper, it is also precluded.
} 
1(1), the frontier line for 1990 in Figure 1(2) moves upwards, suggesting that technology has significantly progressed. Furthermore, there are now greater differences in output and capital stock among countries. With this dataset, we used random-effects estimations to reduce omitted variable bias caused by the time-invariant features of the various countries. ${ }^{10}$ We also incorporated year dummies into this model to capture individually invariant time-specific effects. The estimated function takes the following form:

$G r_{i T-t o}=\alpha_{0}+\alpha_{1} \operatorname{Ln}$ (Output) $_{i t 0}+\alpha_{2}$ (Ethnic polarization) $_{i}+\alpha_{3}$ (Number of natural

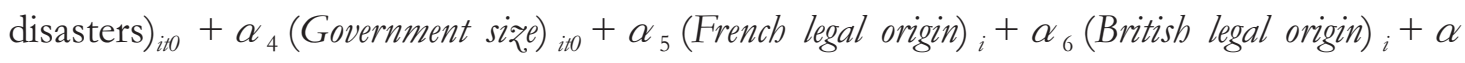

${ }_{7}(\text { Latitude })_{i}+\alpha_{8}(\text { Land size })_{i}+\varepsilon_{i}+v_{t}+u_{i p}$

where $G r_{i T-t o}$ represents labor productivity growth and the change in any of the two dependent variables (i.e., Efficiency and Capital) in country $i$ from each base year t0 to next year $\mathrm{T}(\mathrm{t} 0=1965, \ldots, 1989$ and $T=1966, \ldots, 1990)$. Technological progress (change in technology) for all countries is fixed exogenously by a world production frontier. Hence, the characteristics of each country do not influence technological progress. To put it differently, technological progress is exogenously determined for the countries and so cannot be used as a dependent variable. The estimation model basically follows the model of Kumar and Russell (2002) and therefore $\operatorname{Ln}($ Output), the log of GDP per capita, is included to capture the level of economic development. ${ }^{11}$ Data of dependent variables and $\operatorname{Ln}\left(\right.$ Output) are sourced from the Penn World Table (PWT 5.6). ${ }^{12} \alpha$ represents regression parameters, $\varepsilon$ is the time-invariant individual effect of each country, $v$ represents the year specific effects, and $u$ is an error term. As stated earlier, $\varepsilon$ and $v$ are controlled. The key independent variable that captures ethnic heterogeneity is the ethnic polarization index. Classical works have previously used an ethnic fractionalization index to capture ethnic heterogeneity (Mauro, 1995; Easterly and Levine, 1997). The index is defined as,

\footnotetext{
10 The independent variables used in this paper were not available for 2 of the 57 countries. Hence, data from just 55 countries were used in the estimation, which are identified in Table A2, in the Appendix. 11 In alternative estimations, instead of the log for GDP per capita, the initial level of technical efficiency (level of capital stock) is included when change in technical efficiency (capital accumulation) is examined. In these alternative estimations using a random-effects model, the results for ethnic heterogeneity are similar to those reported in this paper. However, the Hausman test does not reject the null hypothesis that the results of a fixed-effects model are systematically different from those of a random-effects model. This suggests that the results of an estimation using a random-effects model suffers from estimation bias. However, the effect of ethnic heterogeneity is captured completely by country-specific effects in a fixed-effects model. Hence, the results of an alternative specification are not reported in this paper, but are available upon request to the author.

12 The data are available from Center of International Comparisons at the University of Pennsylvania. http://pwt.econ.upenn.edu/ (accessed May 1, 2007).
} 


\section{Fractionallzation $=1-\sum_{i=1}^{n} \boldsymbol{\pi}_{1}^{2}$}

where if I consider ethnic diversity, $\pi_{\mathrm{i}}$ is the proportion of people who profess to belong to ethnic group i. Basically, this indicator can be interpreted as measuring the probability that two randomly selected individuals in a country will belong to different groups.

In addition to the ethnic fractionalization index, an ethnic polarization index has also been developed and used as an alternative measure (Montalvo and Reynal-Querol, 2005a, 2005b; Reynal-Querol, 2002). The ethnic polarization index can be defined as

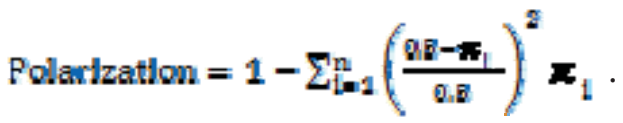

This index measures the normalized distance of a particular distribution of ethnic groups within a bimodal distribution.

To check the robustness of the estimation results, we used both ethnic fractionalization and ethnic polarization as proxy variables for ethnic heterogeneity. ${ }^{13}$ Ethnic heterogeneity is expected to result in conflict, hampering the cooperation and communication required to enhance technology diffusion, and therefore efficiency improvements. Proxies for ethnic heterogeneity hold time-invariant features. Hence, their effects cannot be estimated when a fixed-effects model is used. To examine these effects, a random-effects model is used in this paper. If the coefficients of the proxies take the negative sign when efficiency improvement (and capital accumulation) is a dependent variable, then Hypothesis 1 (and 2) are supported.

The other independent variables used in this model are the values in the base year t0. Natural disasters are considered to influence economic growth (Skidmore and Toya, 2002). To capture this effect, the number of natural disasters that have occurred in the sample countries are included. ${ }^{14}$ We investigate how a natural disaster occurring in year $\mathrm{t} 0$ affects growth rates between $\mathrm{t} 0$ and $\mathrm{t} 1$. For instance, we examine the effect of the number of natural disasters in 1965 on growth rates from 1965 to $1966 .{ }^{15}$ As suggested by Yamamura (2011), government size hinders capital accumulation and so hampers

13 Data on ethnic fractionalization and polarization is available at http://www.econ.upf.edu/ reynal/data web.htm (accessed on June 1, 2011).

14 The data were obtained from the International Disaster Database http://www.emdat.be (accessed on June 1, 2011).

15 Wars and civil disturbances are also considered to have an effect on growth. However, in less developed countries, discontent regarding governmental economic polity increases, which possibly triggers a civil war or disturbance. That is, the occurrence of wars and civil disturbances are thought to be influenced by economic growth. Hence, wars and civil disturbances can be considered as endogenous variables, resulting in estimation bias. It is for this reason that these variables are not incorporated as independent variables. 
economic growth. Hence, government size is included as an independent variable. Government size is measured by a country's general government final consumption expenditure (\% of GDP) sourced from the World Bank (2006). To capture the human capital effect, the number of years at school is incorporated, as used by Easterly and Levine (1997). ${ }^{16}$

Institutional factors appear to play an important role in determining economic growth. A number of previous works have shown that legal origin is profoundly associated with incentives for economic agents and, therefore, economic performance (e.g., La Porta et al., 1997, 1998, 1999, 2008). Better-developed financial systems contribute to growth in capital-intensive sectors (Rajan and Zingales 1998). Further, Levine (1998) argued that legal origin exogenously determined the degree of financial development that promoted economic growth. La Porta et al. (1998) asserted that French civil-law countries offer the weakest legal protection to investors while British common law countries offer the strongest. French and British legal origin dummies are incorporated to capture these effects. ${ }^{17}$ Apart from institutional factors, geographical factors such as latitude and land size are incorporated as independent variables to capture the existence of natural resources and climate.

The source of each variable is presented in Table A2 (Appendix). Table 1 shows the basic statistics of each variable used in the estimation (mean value, standard deviation, maximum value and minimum value). Furthermore, Table 2 presents a correlation matrix of each variable. Table 2 shows that the proxies of ethnic heterogeneity are negatively correlated with labor productivity growth (efficiency improvement and capital accumulation). Further, the correlation between them is statistically significant at the $1 \%$ level. This is consistent with the prediction. However, for a more detailed examination, the regression results must also be studied. ${ }^{18}$

\footnotetext{
16 The number of years at school is available only for 1960, 1970, and 1980. Therefore, to construct the panel data, additional data were generated by interpolation based on the assumption of constant changes in rates to compensate for this deficiency. After 1980, the value for 1980 is used. The data are available from http://econ.worldbank.org/WBSITE/EXTERNAL/EXTDEC/EXTRESEARCH/0,,contentMDK:20700 002 pagePK:64214825 piPK:64214943 theSitePK:469382,00.html (accessed June 2, 2011).

17 Besides legal origins, institutional factors captured by, for instance, corruption and transparency of government appear to influence economic growth. However, the variables used to capture them are regarded as endogenous variables because the causality between these factors and economic growth is ambiguous. Hence, these variables lead to estimation bias and are not used in this paper. In contrast, legal origin is related to historical event. Therefore, legal origin dummies can be considered as exogenous variables and are used in this paper.

18 Correlation between British legal origin and French legal origin countries is -0.67 and statistically significant at the $1 \%$ level. With the exception of British legal origin and French legal origin countries, all other legal origin countries (German legal origin and Scandinavian legal origin countries) are included in the sample. That is, even if a country is not a French legal origin country, there is the possibility that the country is not a British legal origin country.
} 
The estimation results of the random-effects model with year dummy variables from 1966 to 1990 are reported in Tables 3-5. The results based on all observations available for the estimation are exhibited in columns (1) and (3) of each table. However, it is well known that DEA frontier estimates are strongly influenced by outliers. Hence, we also conducted an estimation where outliers were excluded to see how sensitive the estimates are to their removal. As shown in Figures 1(1) and (2), there are countries located on the frontier line, such as the United States (USA), Luxemburg (LUX), and Hong Kong (HKG). Other countries, such as Canada, Switzerland (CHL) and Norway (NOR), are further away. These countries can be considered as outliers and therefore estimations are conducted with these countries excluded. These countries are included in columns (1) and (3), but not in columns (2) and (4) in Table 3, 4 and 5. There were 1,312 observations used in the estimations for columns (1) and (3), whereas 1,187 were used for columns (2) and (4). Hence, excluding outliers reduced the sample size by $9.5 \%$. Table 3 presents the results when labor-productivity growth is used as a dependent variable. Tables 4 shows the results when efficiency improvement is used as independent variables. Tables 5 reports the results when capital accumulation is used as independent variables. The ethnic fractionalization and ethnic polarization indexes are used as a proxy for ethnic heterogeneity in each table. An F-test was conducted to check for unobservable individual effects and time effects. In all columns in Tables 3-5, the results of the F-test indicate that unobservable individual effects and time effects exist. Hence, these effects need to be controlled using a fixed effects or random-effects estimation. In all columns in Tables 3-5, with the exception of column (4) of Table 3, the Hausman test does not reject the null-hypothesis that the differences in coefficients between a fixed-effects model and a random-effects model are not systematic. This result implies that the random-effects model is valid and preferred.

We see in Table 3 that ethnic fractionalization yields the negative sign in columns (1) and that ethnic polarization produces the negative sign in columns (3). Furthermore, they are statistically significant in columns (1) and (3). This implies that ethnic heterogeneity hampers labor-productivity growth. In addition, number of natural disasters shows a significant positive sign in columns (1), which is consistent with the argument of Skidmore and Toya (2002), where natural disasters may stimulate economic growth. Other variables do not show a significant sign in column (3), and hence they do not influence growth. As shown in columns (2) and (4), the results do not change when outliers are 
excluded. This indicates that the results for ethnic heterogeneity are robust.

With respect to Table 4, the coefficient signs of ethnic fractionalization are negative in columns (1), and that of ethnic polarization are also negative in columns (3). In addition, they are statistically significant. I interpret this result as suggesting that ethnic heterogeneity impedes information spillover. Furthermore, the results in columns (2) and (4) suggest that the results do not change when outliers are excluded. This indicates that the results for columns (1) and (3) are robust. Hence, the detrimental effect of ethnic heterogeneity on growth comes in part from the detrimental effect of ethnic heterogeneity on information spillover. Thus, Hypothesis 1 is not strongly supported by the result. Concerning the other variables, the results are almost identical to the results presented in Table 3.

We see from Table 5 that the signs of the proxies for ethnic heterogeneity are positive in column (1) and negative in columns (2)-(4). However, they are not statistically significant. This indicates that outliers do not influence the results for ethnic heterogeneity. Ethnic heterogeneity does not affect capital accumulation, which is not consistent with the argument that ethnic heterogeneity reduces investment (Mauro, 1995). Hence, Hypothesis 2 is not supported by the results. Considering Tables 3-5 jointly, we assert that ethnic heterogeneity impedes information spillover rather than investment. The combined effects of ethnic heterogeneity become negative on growth. Thus, we conclude that ethnic heterogeneity is an obstacle rather than an engine of economic growth.

\section{CONCLUSIONS}

There are conflicting views regarding the role of heterogeneity (or diversity) on growth. Social heterogeneity is considered to impede investment, reducing capital accumulation. What is more, heterogeneity is thought to hinder information spillover, which hampers efficiency improvement. These have a detrimental effect on economic growth. This paper attempts to examine the influence of heterogeneity on economic growth by scrutinizing the channels through which heterogeneity affects such growth.

For this purpose, this study used panel data from 55 countries, from 1965 to 1989, to decompose the effect of ethnic heterogeneity, and to examine how it influences economic growth. Using a random-effects regression model with year dummies, we found that ethnic heterogeneity has a negative effect on growth, mainly by hampering efficiency improvement, but not capital accumulation. We interpret these results to imply that ethnic heterogeneity hinders cooperation and communication among individuals; however, cooperation and communication are important for technology diffusion as well. As a consequence, efficiency improvement is hampered, thereby impeding economic growth. 
In contrast, heterogeneity does not affect capital accumulation.

Information spillover plays an important role for developing countries; it enables them to catch up with more developed countries because it is otherwise difficult for them to create new technology (Vernon, 1966). From the findings in this paper, we derive the argument that heterogeneity is an obstacle to economic development, particularly for developing countries trying to catch up with developed countries via the acquisition of advanced technology.

Information spillover, via interactions among workers from various industries, is thought to largely occur in urban rather than suburban and rural areas (Jacobs, 1969, 1984). Geographical factors were not considered in this research when the estimations were conducted because this paper used country-level macro data. Micro-level data should be used to more closely explore the effect of heterogeneity on information spillover and therefore efficiency improvement. Furthermore, the influence of institutional factors on investment differs between private and public investment (Baliamoune-Lutz and Ndikumana, 2008). However, due to data limitations, our research was unable to examine how heterogeneity influences private and public capital accumulation. These remaining issues can be addressed in future research. 


\section{REFERENCES}

Alesina, A., Baqir, R., Easterly, W. (1999). Public goods and ethnic divisions. Quarterly Journal of Economics, 114 (4), 1243- 1284.

Alesina, A., Devleeschauwer, A., Easterly, W., Kurlat, S., Wacziarg, R., (2003). Fractionalization. Journal of Economic Growth, 8 (2), 155- 194.

Alesina. A., La Ferrara, E. (2005). Ethnic diversity and economic performance. Journal of Economic Literature, 43, 762-800.

Baliamoune-Lutz, M., Ndikumana, L. 2008. Corruption and growth in African countries: Exploring the investment channel. Working Papers 2008-8, University of Massachusetts Amherst, Department of Economics.

Beugelsdijk, S., de Groot, H.L.F., van Schaik. (2004). Trust and economic growth: a robustness analysis. Oxford Economic Papers, 56, 118-134.

Beugelsdijk, S., van Schaik, T. (2005). Social capital and growth in European regions: an empirical test. European Journal of Political Economy, 21, 301-324.

Dincer, O.C. (2011). Ethnic diversity and trust. Contemporary Economic Policy, 29(2), 284-293.

Easterly, B. (2001).The Elusive Quest for Growth: Economists' Adventures and Misadventures in the Tropics. Cambridge: MIT Press.

Easterly, B., Levine, R., (1997). Africa's growth tragedy: policies and ethnic divisions. Quarterly Journal of Economics, 112 (4), 1203-1250.

Henderson, J.D., Russell, R.R., (2005). Human capital and convergence: a production-frontier approach. International Economic Review, 46, 1167-1205.

Isaksson, A. (2011). Social divisions and institutions: assessing institutional parameter variation. Public Choice, 147, 331-357.

Jacobs, J. (1969). The Economies of Cities. New York; Vintage.

Jacobs, J. (1984). The Wealth of Nations: Principles of Economic Life. New York; Vintage.

Kumar, S., Russell, R.R., (2002). Technological change, technological catch-up, and capital deepening: relative contributions to growth and convergence. American Economic Review, 92, 527-548.

La Porta, R., Lopez de Silanes, F., Shleifer, A. and Vishni, R. (1997). Legal deterrents of external finance. Journal of Finance, 57(3), 1131-1150.

La Porta, R., Lopez de Silanes, F., Shleifer, A. and Vishni, R. (1998). Law and finance. Journal of Political Economy, 106(6), 1113-1150.

La Porta, R., Lopez de Silanes, F., Shleifer, A. and Vishni, R. (1999). Quality of government. Journal of Law, Economics and Organization, 15(1), 222-279.

La Porta, R., Lopez de Silanes, F. and Shleifer, A. (2008). The economic consequence of 
legal origins. Journal of Economic Literature, 46(2), 285-332.

Levine, R. (1998). The legal environment, banks, and long-run economic growth. Journal of Money, Credit and Banking, 30(3), pp.596-613.

Lind, J.T. (2007). Fractionalization and the size of government. Journal of Public Economics, 91, 51-76.

Marshall, A. (1920). Principles of Economics. London: Macmillan Press.

Mauro, P., (1995). Corruption and Growth. Quarterly Journal of Economics, 110, 681- 712.

Montalvo, J.G., Reynal-Querol, M. (2003). Religious polarization and economic development. Economics Letters, 80, 201-210.

Montalvo, J.G., Reynal-Querol, M. (2005 a). Ethnic polarization, potential conflict and civil war, American Economic Review, 95(3). 796-816.

Montalvo, J.G., Reynal-Querol, M. (2005 b). Ethnic diversity and economic development, Journal of Development Economics, 76. 293-323.

Mueller, D.C. (2003). Public Choice III. New York: Cambridge University Press.

Munshi, K. (2004). Social learning in a heterogeneous population: technology diffusion in the Indian Green Revolution. Journal of Development Economics, 73, 185-213.

Nishimizu, M., Page, J. (1982). Total factor productivity growth, technological progress and technical efficiency change: dimensions of productivity change in Yugoslavia, 1965-78, Economic Journal 92, 920-936.

Raimbaev, A. (2011). The case of transition economies: what institutions matter for growth?, Journal of Economics and Econometrics, 54(2), -33.

Rajan, R.G., Zengales, L. (1998). Financial development and growth. American Economic Review, 88, 559-586.

Reynal-Querol, M. (2002) Ethnicity, political systems and civil war, Journal of Conflict Resolution, 46, 29-54.

Skidmore, M., Toya, H. (2002). Do natural disasters promote long-run growth?, Economic Inquiry, 40(4),664-687.

Thornton, R.A., Thompson, P. (2001). Learning from experience and learning from others: An exploration of learning and spillovers in Wartime Shipbuilding. American Economic Review, 91(5), 1350-1368.

Vernon, R. (1966). International investment and international trade in the product cycle. Quarterly Journal of Economics, 80, 190-207.

World Bank, (2006). World Development Indicators, CD-ROM, World Bank, Washington, D.C.

Yamamura, E., Shin, I., (2007a). Technological change and catch-up and capital deepening: relative contributions to growth and convergence: Economics Bulletin, 15(3), 1-8. 
Yamamura, E., Shin, I., (2007b). Dynamics of agglomeration economies and regional industrial structure: The case of the assembly industry of the greater Tokyo Region, 1960-2000. Structural Change and Economic Dynamics, 18(4),483-499.

Yamamura, E., Shin, I., (2008). The benefit of efficiency improvement on growth and convergence: a study using Japan panel data. Economics Letters, 99, 209-211.

Yamamura, E., Shin, I., (2012). Heterogeneity, Trust, Human Capital and Productivity Growth: Decomposition Analysis. Journal of Economics and Econometrics, 55(2), 51-77.

Yamamura, E., (2011). Decomposition of the effect of government size on growth. Economics Letters, 112(3), 230-232.

Zak, P.J., Knack, S. (2001). Trust and growth. Economic Journal, 111, 295-321. 


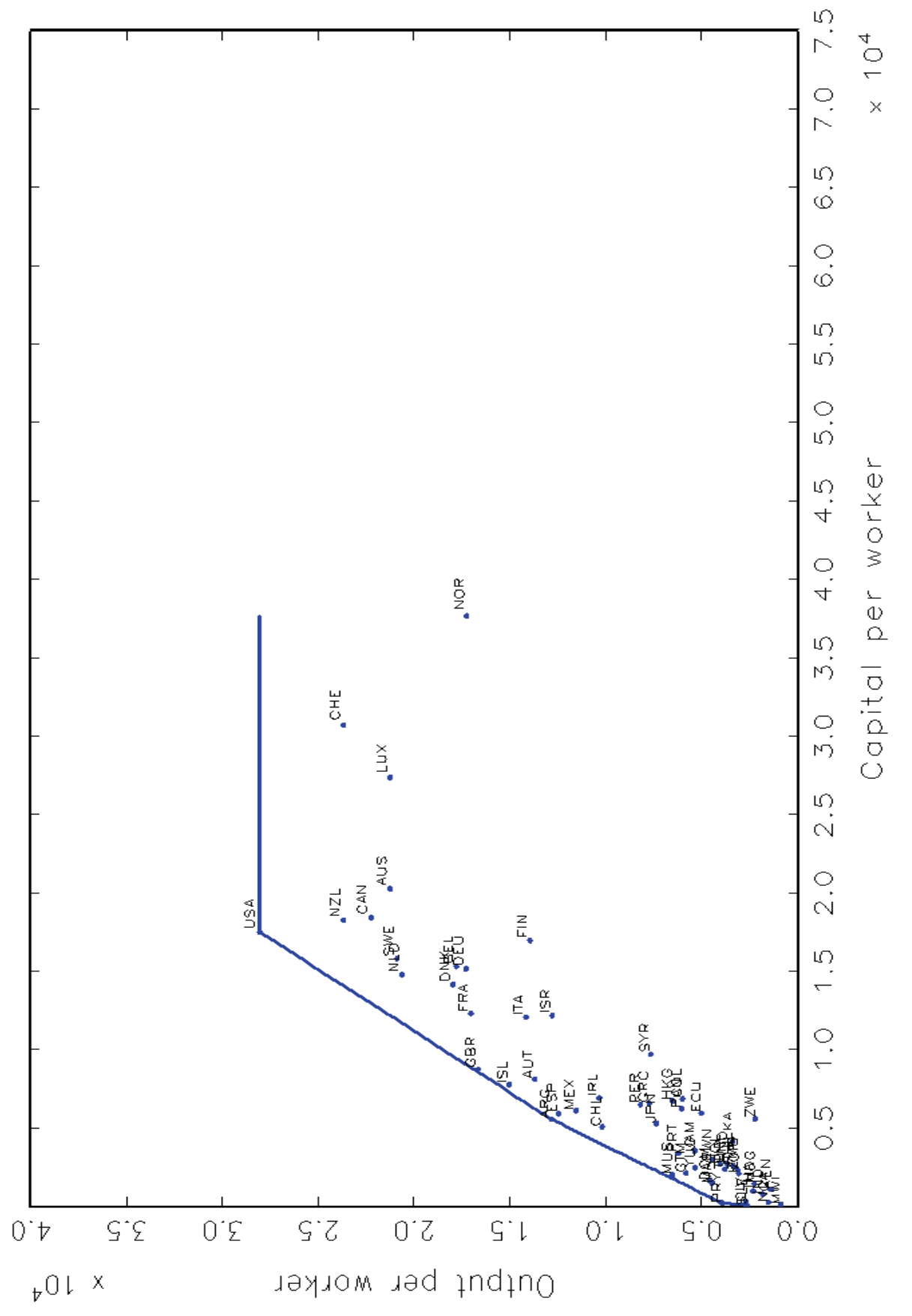




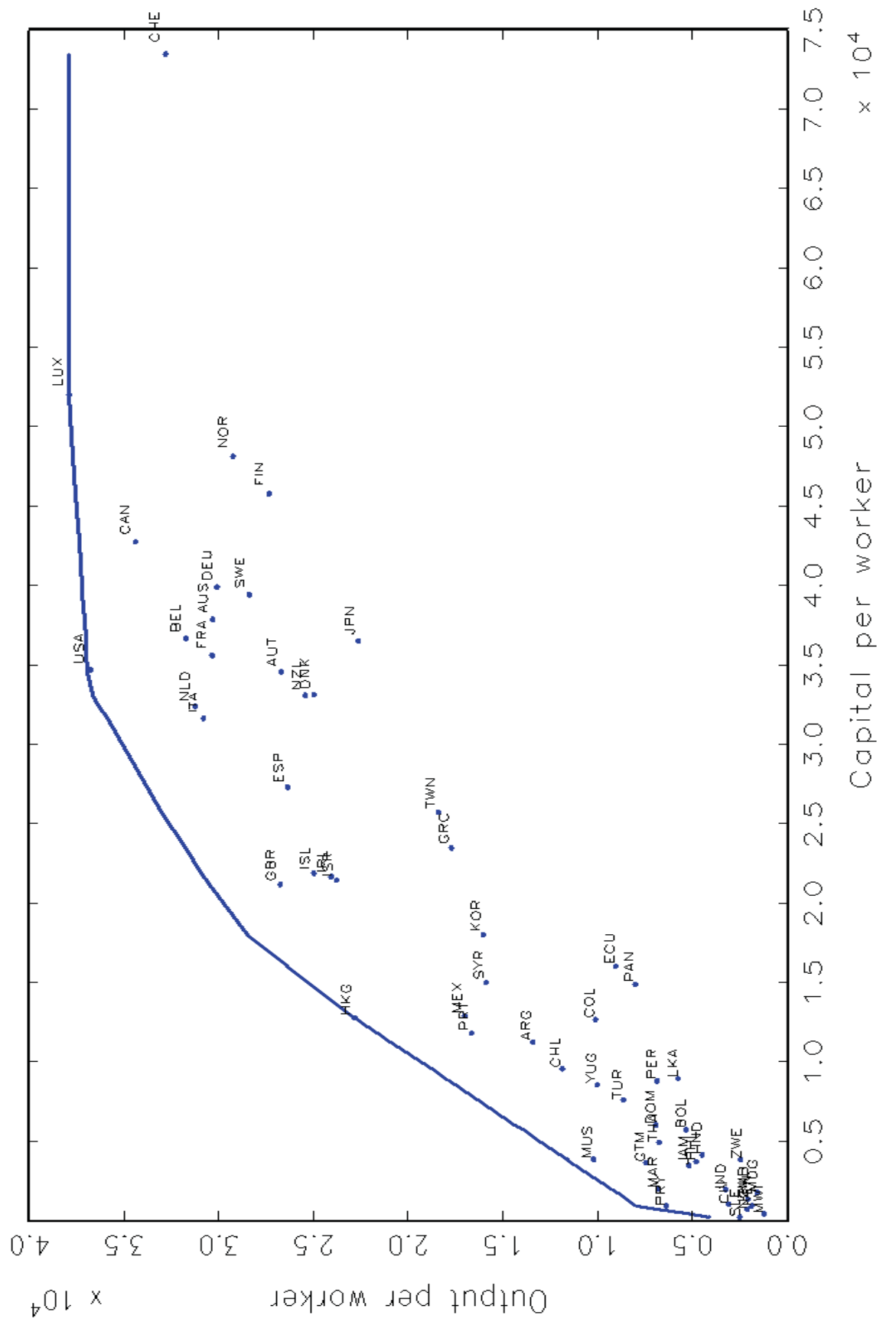

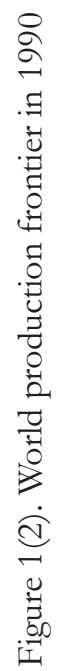




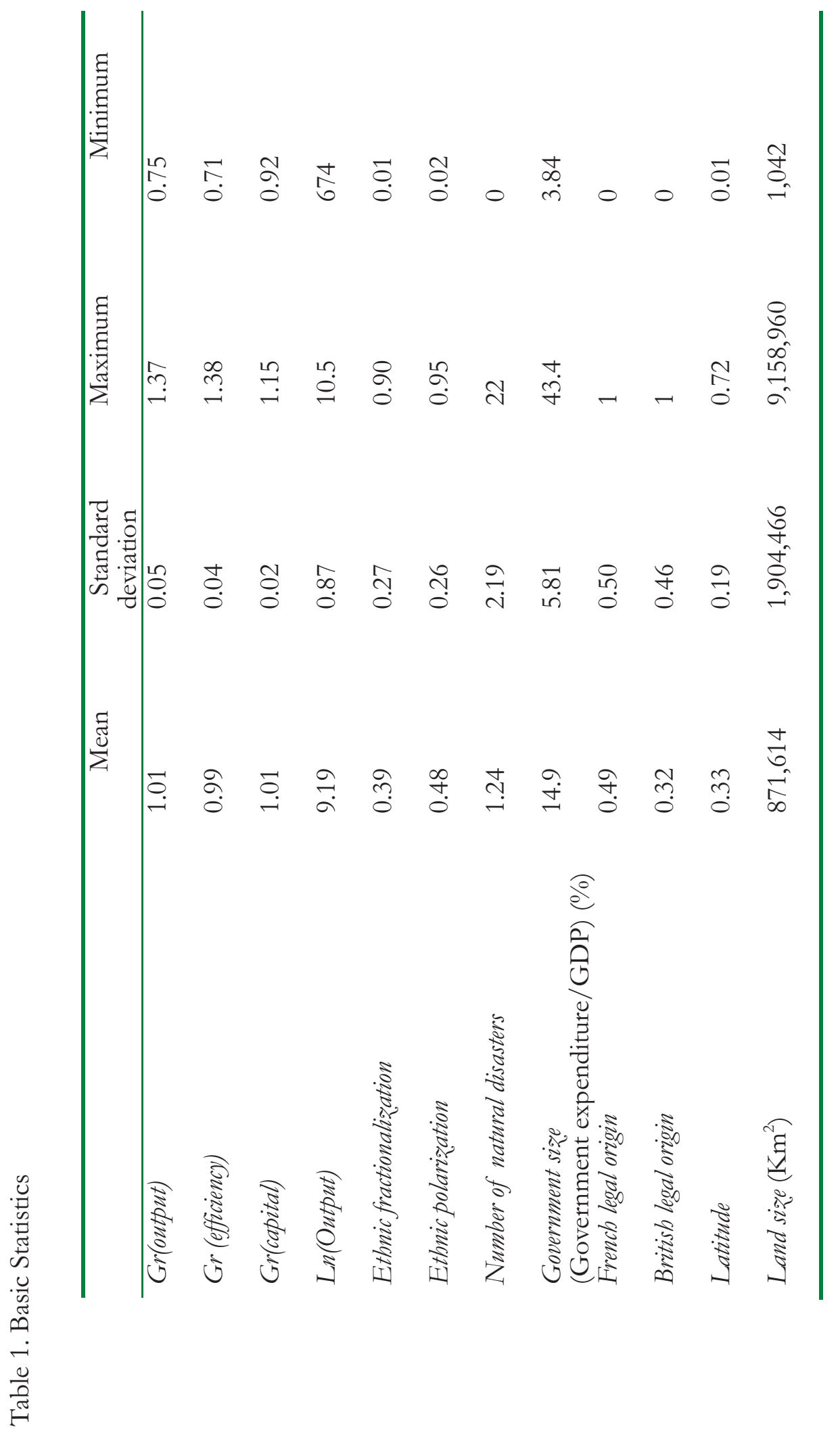




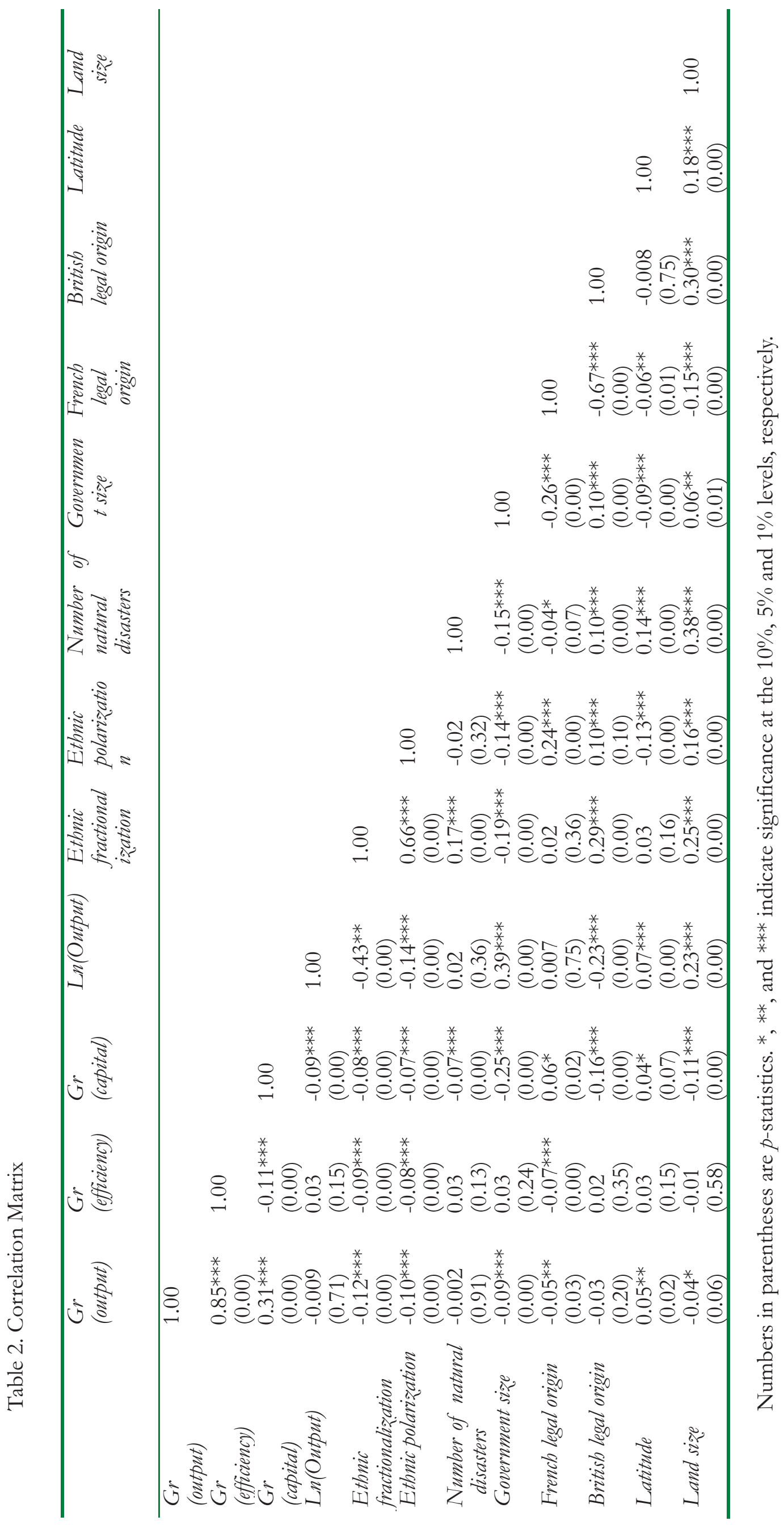


Table 3. Determinants of labor-productivity growth (random-effects estimates: 1965-1989)

\begin{tabular}{|c|c|c|c|c|}
\hline & $\begin{array}{l}\text { (1) } \\
\text { Full sample }\end{array}$ & $\begin{array}{l}\quad(2) \\
\text { Excluding } \\
\text { outliers }\end{array}$ & $\begin{array}{c}\text { (3) } \\
\text { Full sample }\end{array}$ & $\begin{array}{l}\quad(4) \\
\text { Excluding } \\
\text { outliers }\end{array}$ \\
\hline Ln(Output) & $\begin{array}{l}-0.001 \\
(-0.52)^{-}\end{array}$ & $\begin{array}{l}-0.002 \\
(-0.73)^{-}\end{array}$ & $\begin{array}{l}0.002 \\
(0.91)^{-}\end{array}$ & $\begin{array}{l}0.001 \\
(0.44)^{-}\end{array}$ \\
\hline Ethnic fractionalization & $\begin{array}{l}-0.030 * * * \\
(-3.45)\end{array}$ & $\begin{array}{l}-0.030 * * * \\
(-3.19)\end{array}$ & & \\
\hline Ethnic polarization & & & $\begin{array}{l}-0.020 * * \\
(-2.28)\end{array}$ & $\begin{array}{l}-0.018^{*} \\
(-1.96)\end{array}$ \\
\hline $\begin{array}{l}\text { Number of natural } \\
\text { disasters }\end{array}$ & $\begin{array}{l}0.001 * \\
(1.86)\end{array}$ & $\begin{array}{l}0.001 \\
(1.57)\end{array}$ & $\begin{array}{l}0.001 \\
(1.43)\end{array}$ & $\begin{array}{l}0.001 \\
(0.99)\end{array}$ \\
\hline Government size & $\begin{array}{l}-0.001 * \\
(-1.77)\end{array}$ & $\begin{array}{l}-0.001 * \\
(-1.58)\end{array}$ & $\begin{array}{l}-0.001 * \\
(-1.97)\end{array}$ & $\begin{array}{l}-0.001 * \\
(-1.65)\end{array}$ \\
\hline French legal origin & $\begin{array}{l}-0.007 \\
(-1.06)\end{array}$ & $\begin{array}{l}-0.007 \\
(-1.03)\end{array}$ & $\begin{array}{l}-0.007 \\
(-1.05)\end{array}$ & $\begin{array}{l}-0.008 \\
(-1.09)\end{array}$ \\
\hline British legal origin & $\begin{array}{l}-0.001 \\
(-0.09)\end{array}$ & $\begin{array}{l}-0.001 \\
(-0.23)\end{array}$ & $\begin{array}{l}-0.002 \\
(-0.32)\end{array}$ & $\begin{array}{l}-0.004 \\
(-0.57)\end{array}$ \\
\hline Latitude & $\begin{array}{l}0.01 \\
(1.49)\end{array}$ & $\begin{array}{l}0.01 \\
(1.12)\end{array}$ & $\begin{array}{l}0.009 \\
(0.95)\end{array}$ & $\begin{array}{l}0.006 \\
(0.57)\end{array}$ \\
\hline Land size & $\begin{array}{l}-0.96 * 10^{9} \\
(-0.79)\end{array}$ & $\begin{array}{l}-2.09 * 10^{9} \\
(-1.09)\end{array}$ & $\begin{array}{l}-1.70^{*} 10^{9} \\
(-1.40)\end{array}$ & $\begin{array}{l}-2.70 * 10^{9} \\
(-1.36)\end{array}$ \\
\hline Constant & $\begin{array}{l}1.05^{* * *} \\
(38.6)\end{array}$ & $\begin{array}{l}1.06^{* * *} \\
(36.3)\end{array}$ & $\begin{array}{l}1.02^{* * *} \\
(39.8)\end{array}$ & $\begin{array}{l}1.03^{* * *} \\
(36.5)\end{array}$ \\
\hline F-test (Year dummies) & $\begin{array}{l}3.28 \\
\text { p-value }=0.00\end{array}$ & $\begin{array}{l}2.79 \\
\mathrm{p} \text {-value }=0.00\end{array}$ & $\begin{array}{l}3.28 \\
\text { p-value }=0.00\end{array}$ & $\begin{array}{l}2.79 \\
\text { p-value }=0.00\end{array}$ \\
\hline $\begin{array}{l}\text { F-test } \quad \text { (Country } \\
\text { dummies) } \\
\text { Hausman test }\end{array}$ & $\begin{array}{l}2.24 \\
\text {--value }=0.00 \\
33.1 \\
p \text {-value }=0.18\end{array}$ & $\begin{array}{l}2.28 \\
\text { p-value }=0.00 \\
25.2 \\
p \text {-value }=0.55\end{array}$ & $\begin{array}{l}2.43 \\
\text { p-value }=0.00 \\
2.08 \\
p \text {-value }=0.99\end{array}$ & $\begin{array}{l}2.49 \\
p \text {-value }=0.00 \\
41.1 \\
p \text {-value }=0.04\end{array}$ \\
\hline $\begin{array}{l}\text { Groups } \\
\text { Observations }\end{array}$ & $\begin{array}{l}55 \\
1,312 \\
\end{array}$ & $\begin{array}{l}50 \\
1,187\end{array}$ & $\begin{array}{l}55 \\
1,312\end{array}$ & $\begin{array}{l}50 \\
1,187\end{array}$ \\
\hline
\end{tabular}

Note: Year dummies are not reported but are included in all estimations as independent variables. Numbers in parentheses are $z_{\text {-statistics. }}^{*},{ }^{* *}$, and $* * *$ indicate significance at the $10 \%, 5 \%$ and $1 \%$ levels, respectively. 
Table 4. Determinants of efficiency improvement (random-effects estimates: 1965-1989)

\begin{tabular}{|c|c|c|c|c|}
\hline & $\begin{array}{l}(1) \\
\text { Full sample }\end{array}$ & $\begin{array}{l}\quad(2) \\
\text { Excluding } \\
\text { outliers }\end{array}$ & $\begin{array}{c}\text { (3) } \\
\text { Full sample }\end{array}$ & $\begin{array}{l}\quad(4) \\
\text { Excluding } \\
\text { outliers }\end{array}$ \\
\hline Ln(Output) & $\begin{array}{l}-0.001 \\
(-0.06)^{-}\end{array}$ & $\begin{array}{l}-0.001 \\
(-0.56)\end{array}$ & $\begin{array}{l}0.002 \\
(1.40)^{-}\end{array}$ & $\begin{array}{l}0.001 \\
(0.58)^{-}\end{array}$ \\
\hline Ethnic fractionalization & $\begin{array}{l}-0.021 * * * \\
(-3.34)\end{array}$ & $\begin{array}{l}-0.018 * * * \\
(-2.80)\end{array}$ & & \\
\hline Ethnic polarization & & & $\begin{array}{l}-0.013^{* *} \\
(-2.26)\end{array}$ & $\begin{array}{l}-0.010^{*} \\
(-1.68)\end{array}$ \\
\hline $\begin{array}{l}\text { Number of natural } \\
\text { disasters }\end{array}$ & $\begin{array}{l}0.001 * \\
(1.78)\end{array}$ & $\begin{array}{l}0.001 * \\
(1.68)\end{array}$ & $\begin{array}{l}0.001 \\
(1.24)\end{array}$ & $\begin{array}{l}0.001 \\
(1.10)\end{array}$ \\
\hline Government size & $\begin{array}{l}0.0001 \\
(0.50)\end{array}$ & $\begin{array}{l}0.0002 \\
(0.91)\end{array}$ & $\begin{array}{l}0.001 \\
(1.24)\end{array}$ & $\begin{array}{l}0.0002 \\
(0.75)\end{array}$ \\
\hline French legal origin & $\begin{array}{l}0.001 \\
(0.50)\end{array}$ & $\begin{array}{l}-0.001 \\
(-0.26)\end{array}$ & $\begin{array}{l}-0.004 \\
(-0.08)\end{array}$ & $\begin{array}{l}-0.002 \\
(-0.45)\end{array}$ \\
\hline British legal origin & $\begin{array}{l}0.001 \\
(0.01)\end{array}$ & $\begin{array}{l}0.004 \\
(0.77)\end{array}$ & $\begin{array}{l}0.006 \\
(1.24)\end{array}$ & $\begin{array}{l}0.002 \\
(0.40)\end{array}$ \\
\hline Latitude & $\begin{array}{l}0.01 \\
(1.44)\end{array}$ & $\begin{array}{l}0.01 \\
(0.67)\end{array}$ & $\begin{array}{l}0.006 \\
(0.90)\end{array}$ & $\begin{array}{l}0.001 \\
(0.23)\end{array}$ \\
\hline Land size & $\begin{array}{l}-0.73^{*} 10^{9} \\
(-0.85)\end{array}$ & $\begin{array}{l}-1.33^{*} 10^{9} \\
(-0.99)\end{array}$ & $\begin{array}{l}-1.19 * 10^{9} \\
(-1.37)\end{array}$ & $\begin{array}{l}-1.63 * 10^{9} \\
(-1.22)\end{array}$ \\
\hline Constant & $\begin{array}{l}0.99 * * * \\
(49.2)\end{array}$ & $\begin{array}{l}1.00^{* * *} \\
(47.6)\end{array}$ & $\begin{array}{l}0.96^{* * *} \\
(51.4)\end{array}$ & $\begin{array}{l}0.98^{* * *} \\
(49.9)\end{array}$ \\
\hline F-test (Year dummies) & $\begin{array}{l}3.43 \\
p \text {-value }=0.00\end{array}$ & $\begin{array}{l}2.78 \\
p \text {-value }=0.00\end{array}$ & $\begin{array}{l}3.43 \\
p \text {-value }=0.00\end{array}$ & $\begin{array}{l}2.78 \\
p \text {-value }=0.00\end{array}$ \\
\hline $\begin{array}{l}\text { F-test } \quad \text { (Country } \\
\text { dummies) } \\
\text { Hausman test }\end{array}$ & $\begin{array}{l}1.95 \\
\text { p-value }=0.00 \\
28.4 \\
\text { p-value }=0.38\end{array}$ & $\begin{array}{l}1.90 \\
p \text {-value }=0.00 \\
19.1 \\
p \text {-value }=0.85\end{array}$ & $\begin{array}{l}2.06 \\
\text { p-value }=0.00 \\
36.4 \\
\text { p-value }=0.11\end{array}$ & $\begin{array}{l}2.00 \\
\text { p-value }=0.00 \\
30.7 \\
\text { p-value }=0.28\end{array}$ \\
\hline $\begin{array}{l}\text { Groups } \\
\text { Observations }\end{array}$ & $\begin{array}{l}55 \\
1312\end{array}$ & $\begin{array}{l}50 \\
1187\end{array}$ & $\begin{array}{l}55 \\
1312 \\
\end{array}$ & $\begin{array}{l}50 \\
1187\end{array}$ \\
\hline
\end{tabular}

Note: Year dummies are not reported but are included in all estimations as independent variables. Numbers in parentheses are z-statistics. $^{*}, * *$, and $* * *$ indicate significance at the $10 \%, 5 \%$ and $1 \%$ levels, respectively. 
Table 5. Determinants of capital accumulation (random-effects estimates: 1965-1989)

\begin{tabular}{|c|c|c|c|c|}
\hline & $\begin{array}{l}(1) \\
\text { Full sample }\end{array}$ & $\begin{array}{l}\quad(2) \\
\text { Excluding } \\
\text { outliers }\end{array}$ & $\begin{array}{c}\text { (3) } \\
\text { Full sample }\end{array}$ & $\begin{array}{l}\quad(4) \\
\text { Excluding } \\
\text { outliers }\end{array}$ \\
\hline Ln(Output) & $\begin{array}{c}0.004 * * * \\
(2.81)^{-}\end{array}$ & $\begin{array}{c}0.005^{* * *} \\
(3.07)^{-}\end{array}$ & $\begin{array}{c}0.004 * * * \\
(3.01)^{-}\end{array}$ & $\begin{array}{l}0.005^{* * *} \\
(3.40)^{-}\end{array}$ \\
\hline Ethnic fractionalization & $\begin{array}{l}0.0007 \\
(0.11)\end{array}$ & $\begin{array}{l}-0.001 \\
(-0.17)\end{array}$ & & \\
\hline Ethnic polarization & & & $\begin{array}{l}-0.003 \\
(-0.58)\end{array}$ & $\begin{array}{l}-0.005 \\
(-0.79)\end{array}$ \\
\hline $\begin{array}{c}\text { Number of natural } \\
\text { disasters }\end{array}$ & $\begin{array}{l}0.003 \\
(1.34)\end{array}$ & $\begin{array}{l}0.002 \\
(0.86)\end{array}$ & $\begin{array}{l}0.003 \\
(1.31)\end{array}$ & $\begin{array}{l}0.002 \\
(0.82)\end{array}$ \\
\hline Government size & $\begin{array}{l}-0.001 * * * \\
(3.99)\end{array}$ & $\begin{array}{l}-0.001 * * * \\
(3.92)\end{array}$ & $\begin{array}{l}-0.001 * * * \\
(4.00)\end{array}$ & $\begin{array}{l}-0.001 * * * \\
(3.93)\end{array}$ \\
\hline French legal origin & $\begin{array}{l}-0.004 \\
(-0.98)\end{array}$ & $\begin{array}{l}-0.002 \\
(-0.48)\end{array}$ & $\begin{array}{l}-0.003 \\
(-0.61)\end{array}$ & $\begin{array}{l}-0.001 \\
(-0.10)\end{array}$ \\
\hline British legal origin & $\begin{array}{l}-0.006 \\
(-1.13)\end{array}$ & $\begin{array}{l}-0.003 \\
(-0.54)\end{array}$ & $\begin{array}{l}-0.004 \\
(-0.83)\end{array}$ & $\begin{array}{l}-0.001 \\
(-0.21)\end{array}$ \\
\hline Latitude & $\begin{array}{l}0.004 \\
(0.67)\end{array}$ & $\begin{array}{l}0.007 \\
(0.95)\end{array}$ & $\begin{array}{l}0.004 \\
(0.61)\end{array}$ & $\begin{array}{l}0.007 \\
(0.90)\end{array}$ \\
\hline Land size & $\begin{array}{l}-1.79 * 10^{9} * * \\
(-2.13)\end{array}$ & $\begin{array}{l}-2.35 * 10^{9} * \\
(-1.79)\end{array}$ & $\begin{array}{l}-1.70 * 10^{9} * * \\
(-2.06)\end{array}$ & $\begin{array}{l}-2.40 * 10^{9} * \\
(-1.80)\end{array}$ \\
\hline Constant & $\begin{array}{l}0.99 * * * \\
(58.9)\end{array}$ & $\begin{array}{l}0.98^{* * *} \\
(55.4)\end{array}$ & $\begin{array}{l}0.99 * * * \\
(62.1)\end{array}$ & $\begin{array}{l}0.98^{* * *} \\
(57.2)\end{array}$ \\
\hline F-test (Year dummies) & $\begin{array}{l}18.7 \\
\text { p-value }=0.00\end{array}$ & $\begin{array}{l}19.6 \\
p \text {-value }=0.00\end{array}$ & $\begin{array}{l}18.7 \\
\text { p-value }=0.00\end{array}$ & $\begin{array}{l}19.6 \\
\text { p-value }=0.00\end{array}$ \\
\hline $\begin{array}{ll}\text { F-test } & \text { (Country } \\
\text { dummies) } & \\
\text { Hausman test } & \end{array}$ & $\begin{array}{l}10.8 \\
\text { p-value }=0.00 \\
27.9 \\
\text { p-value }=0.41\end{array}$ & $\begin{array}{l}10.8 \\
\text { p-value }=0.00 \\
29.9 \\
\text { p-value }=0.31\end{array}$ & $\begin{array}{l}11.6 \\
\text { p-value }=0.00 \\
26.2 \\
\text { p-value }=0.50\end{array}$ & $\begin{array}{l}11.9 \\
\text { p-value }=0.00 \\
26.8 \\
\text { p-value }=0.47\end{array}$ \\
\hline $\begin{array}{l}\text { Groups } \\
\text { Observations }\end{array}$ & $\begin{array}{l}55 \\
1312\end{array}$ & $\begin{array}{l}50 \\
1187\end{array}$ & $\begin{array}{l}55 \\
1312\end{array}$ & $\begin{array}{l}50 \\
1187\end{array}$ \\
\hline
\end{tabular}

Note: Year dummies are not reported but are included in all estimations as independent variables. Numbers in parentheses are r-statistics. $^{*},{ }^{* *}$, and ${ }^{* * *}$ indicate significance at the $10 \%, 5 \%$ and $1 \%$ levels, respectively. 
Appendix: Table A1. Countries used in DEA

\begin{tabular}{|c|c|c|c|}
\hline code & Country name & code & Country name \\
\hline ARG & Argentina & MWI & Malawi \\
\hline AUS & Australia & MUS & Mauritius \\
\hline AUT & Austria & MEX & Mexico \\
\hline BEL & Belgium & MAR & Morocco \\
\hline BOL & Bolivia & NLD & Netherlands \\
\hline CAN & Canada \# & NZL & New Zealand \\
\hline CHL & Switzerland \# & NGA & Nigeria \\
\hline COL & Colombia & NOR & Norway \# \\
\hline DNK & Denmark & PAN & Panama \\
\hline DOM & Dominican Republic & PRY & Paraguay \\
\hline $\mathrm{ECU}$ & Ecuador & PER & Peru \\
\hline FIN & Finland & PHL & Philippines \\
\hline FRA & France & PRT & Portugal \\
\hline DEU & Germany & SLE & Sierra Leone \\
\hline GRC & Greece & ESP & Spain \\
\hline GTM & Guatemala & LKA & Sri Lanka \\
\hline HND & Honduras & SWE & Sweden \\
\hline $\mathrm{HKG}$ & Hong Kong, China \# & $\mathrm{CHE}$ & Switzerland \\
\hline ISL & Iceland & SYR & Syrian Arab Republic \\
\hline IND & India & TWN & Taiwan, China \#\# \\
\hline IRL & Ireland & THA & Thailand \\
\hline ISR & Israel & TUR & Turkey \\
\hline ITA & Italy & GBR & United Kingdom \\
\hline CIV & Ivory Coast & USA & United States \# \\
\hline JAM & Jamaica & YUG & Yugoslavia \#\# \\
\hline JPN & Japan & ZMB & Zambia \\
\hline $\mathrm{KEN}$ & Kenya & ZWE & Zimbabwe \\
\hline KOR & Korea, Rep. & & \\
\hline LUX & Luxembourg \# & & \\
\hline MDG & Madagascar & & \\
\hline
\end{tabular}

Note: \#\# indicate countries excluded in all columns of Table 3,4 and 5. \# indicates countries excluded in sample used for estimation in columns (2) and (4) of Tables 3, 4 and 5. 
Table A2. Source of data

\begin{tabular}{ll}
\hline & Source \\
\hline Ln(Output) & Penn World Table 5.6 \\
Capital Stock per capita & Penn World Table 5.6 \\
Ethnic fractionalization & Web site of Marta Reynal-Querol $^{\mathrm{a}}$ \\
Ethnic polarization & Web site of Marta Reynal-Querol $^{\mathrm{a}}$ \\
Number of natural disasters & EM-DAT (Emergency Events Database) ${ }^{\mathrm{b}}$ \\
$\begin{array}{l}\text { Government size } \\
\text { Land size }\end{array}$ & World Bank (2006) $_{\text {French legal origin }}$ \\
Writish legal origin & Web site of Andrei Shleifer ${ }^{\mathrm{c}}$ \\
Land size & Web site of Andrei Shleifer ${ }^{\mathrm{c}}$ \\
\hline
\end{tabular}

Note: With the exception of the World Bank (2006), the data was obtained from the internet as follows:

a. http://www.econ.upf.edu/ reynal/data_web.htm (accessed on December 1, 2011).

b. http://www.emdat.be (accessed on June 1, 2011).

c. http://www.economics.harvard.edu/faculty/shleifer/dataset (accessed on June 2, 2011). 